\title{
Earnings Management in Australian Not-for-Profit Disability Services
}

\author{
David Gilchrist ${ }^{\mathrm{a}}$, Dane Etheridge ${ }^{\mathrm{b}}$ and Frank Liu ${ }^{\mathrm{a}}$
}

${ }^{a}$ University of Western Australia, Crawley, 6009, Australia

${ }^{b}$ Curtin University, Bentley, 6102, Australia

\begin{abstract}
The Australian not-for-profit and charitable sector is an important component in that country's social capital. It delivers services and supports to some of the most vulnerable people in the community. However, up until recently, poor data sets related to the sector's financial performance and position have meant that the examination of its financial capacity has been unable to be undertaken. This paper reports on our findings relative to earnings management in the context of Not-for-profit disability service providers. Assessing a longitudinal data set providing financial data relative to 154 such not-for-profits, we have identified that the sector is subject to earnings management, that such activities are aimed at reducing reported profit likely in order for these organisations to meet the normative financial expectations of stakeholders including public sector funders and philanthropists. This finding has significant implications for our understanding of not-for-profit financial, regulatory and audit arrangements in place and accounting standards as they apply to this sector.
\end{abstract}

Key Words: Earnings Management; Not for Profit; Charities

JEL classification: M40; M41; M48

\section{Introduction}

Earnings management has been one of accounting research's most considered topics. It is well documented that reported earnings are managed for various reasons including to achieve performance bonuses, complying with debt covenants, and influencing stock prices (Healy and Wahlen, 1999). The vast majority of earnings management literature has analysed this phenomenon in the for-profit context, typically utilising sample data from of public companies. In the for-profit context, researchers have investigated the extent of earnings management, techniques used to manage earnings, quantification of earnings management, motivations for managing earnings and the consequences of earnings management, as well as policy recommendations aimed at curbing earnings management, producing policy recommendations 
in the process (Schipper 1989; Jones 1991; Burgstahler and Dichev 1997; Healy and Wahlen 1999; Dechow and Skinner 2000; Roychowdhury 2006; Walker 2013).

In contrast, there is a dearth of research into earnings management in the not-for-profit (NFP) context (Vansant 2016; Leone and Van Horn 2005; Ballantine et al. 2008; Verbruggen and Christiaens 2012; Jegers 2013, Gilchrist and Simnett 2019). The NFP sector is not only important in the context of social policy development and implementation (for instance, see Frumkin 2005), it is also a significant part of the economy in developed nations. In 2018 Australian charities (a subgroup of the much larger not-for-profit sector) employed in excess of 1.3 million people and turned over approximately $\$ 155$ billion while holding approximately $\$ 323$ billion in net assets (ACNC 2020). Importantly, a considerable proportion of Australian charities' income comes from public sector procurement, public sector grants and from philanthropic donations - indeed, these income sources represented about half of revenue sources of Australia's charities in that year (Gilchrist 2017; ACNC 2020).

Understanding the motivations for, and implications of, NFP earnings management is an important endeavour. Leaders of NPF's may be induced to manage their financial reports closely because their financial sustainability relies upon external funding, primarily from public and philanthropic sources. A higher profit may suggest that these funds are not needed. Therefore, such management would be aimed at assisting NFPs to ensure their stakeholders providing financial resources continue to provide the support necessary to serve their stakeholders, including some of the community's most vulnerable people. As such, earnings management practices in this sector are more likely to be focused on reducing reported profit rather than the objectives demonstrated in for-profit organisations where they are generally incentivised to report a higher profit.

Additionally, the suitability of accounting standards and other reporting requirements are able to be considered in the context of drivers of earnings management within this sector-the appropriateness of such standards and their prevention or supporting earnings management activities is an important consideration. A major impediment to undertaking research in relation to this sector is the lack of suitable data assets.

Governments around the world are increasingly addressing the data gap through initiatives such as the UK Charity Commission and Australia's Australian Charities and Not-for-profits Commission (ACNC). In countries such as the UK and the United States, where data is available, there have been a number of empirical studies published that document evidence of earnings management in NFP settings, especially in the US where tax return submission 
requirements have increased the data set available for research (Leone and Van Horn 2005; Verbruggen and Christiaens 2012; Jegers 2013; Vansant 2016). There has been a more limited body of research undertaken in the UK, but undertaken never-the-less (Ballantine et al. 2008, Nguyen and Soobaroyen 2018).

In Australia though, a lack of data makes it very difficult for studies relating to earnings management to be undertaken (Gilchrist 2020) because of the limited public reporting requirements set for NFP firms (Gilchrist 2017, Zha et al. 2017). Additionally, in Australia, the data that is collected is not sufficiently granular to be utilised in applying best-practice earnings management research methodology because it does not capture the variables required to estimate discretionary accruals in the way that data related to for-profit organisations does. This lack of granularity is a short coming across the sector (Gilchrist, Knight et al. 2020). Finally, the data collected by the ACNC only applies to approximately 56,000 charities, a sub-group of the estimated 600,000 not-for-profits established in Australia. Therefore, there are likely to be well over half a million NFP organisations for which any sort of analysis is almost impossible.

This study contributes to the earnings management literature by using a unique dataset to investigate the prevalence of earnings management in Australian disability services charities. Indeed, we utilise financial data gathered via a two-year study of a panel of 154 Australian NFP disability services providers conducted between 2015 and 2016. The data gathered included detailed information from these organisation's balance sheets and income statements providing sufficient appropriate data to allow us to undertake a study in earnings management in the context of this cohort. The cohort represents approximately $15.5 \%$ of the charitable disability services sector. However, the respondents providing data were self-selecting and so, while the findings generally conform to our expectations of behaviour across the charitable human services sector, their direct extrapolation is not possible.

Australian NFPs are an interesting sector in which to study earnings management because they operate in a federal environment and within the Australian welfare state where responsibilities for many major social policy settings, that are expensive, are shared between national and sub-national governments (Gilchrist 2020a, Gilchrist 2020b). Like their for-profit counterparts, NFPs face various pressures to manage earnings. For instance, in the United States there has been found to be pressure to report minimal profit in order to meet the normative expectations of funders and others in the community of charities (Vansant 2016), while, in the UK, charities were found to be under pressure to minimise profits but to ensure they did not make a loss in order to demonstrate governance capacity (Nguyen and Soobaroyen 
2019). We expect that similar drivers in Australia will cause those charged with governance to seek to manage earnings in order to protect their organisation's fund-raising capacity.

This paper contributes to the literature by analysing the extent to which earnings management is prevalent in the Australian disability services NFPs. It finds that, in fact, these organisations do succumb to incentives to manage their reported earnings in order to meet their perceptions of philanthropists and other funders' normative expectations regarding financial performance. These expectations lead NFP executives to reduce their reported profits toward zero while being cautious not to report a loss which might invoke concerns regarding sustainability in funders. These findings reflect the findings of studies focusing on specific human services sub-sectors in the United States and in the United Kingdom (for instance, see Vansant 2016 and Nguyen and Soobaroyen 2019).

The next section examines earnings management incentives and we develop our hypothesis, in section three we examine the data and in section four we describe the empirical results. Section five concludes the paper.

\section{Incentives to Manage Earnings and Hypothesis Development}

NFPs "are dependent upon continuing exchanges with the environments in which they operate" (Heimovics et al 1993: 425). They are not isolated from their environment, and their operation is largely dependent upon the flow of resources from outside (Heimovics et al 1993). In order to protect the inflow of vital funding, NFPs may manage earnings in order to influence users of financial reports (Tinkelman 1999; Buchheit and Parsons 2006). Of course, not all stakeholders are expected to influence NFP accounting choices equally. Beattie and Jetty (2009) argue that charities prioritise some stakeholders when preparing financial reports, because of the power those stakeholders have. In this section, we explore the various motivations for earnings management in the Australian NFP context and develop hypotheses from these motivations.

Costs of Reporting Profits

Arguably the strongest motivations for NFP earnings management arise from the expectations of major funders. In the Australian context, the major providers of financial support to NFPs are governments and donors, both of which might show preference towards 
NFPs with low reported profitability, indicating that provided funds were needed and have been utilised effectively. Private donors are often most interested in the financial efficiency of NFPs (such as the ratio of fundraising expenditure to charitable activity expenditure) since high efficiency measures indicate that donated funds have been well deployed (Tinkelman, 1999) Government is often a major stakeholder of NFPs, contributing to the success of an NFP both directly, though funding, and indirectly, through levers such as regulation and other policy frameworks. Since NFPs are incentivised to present their financial reports in a manner to appeal to these stakeholders, they may be motivated to select accounting policies that lead to nearzero reported profitability. Low or negative profitability would imply that NFP managers have deployed financial resources in order to fulfil their charitable purpose and signals that further resources are required (Verbruggen and Christiaens 2012).

Customers and suppliers both have an interest in the financial performance of NFPs and may make decisions based on their perception of the financial strength of an organisation. For example, excessive financial performance increases are likely to increase pressure for pay rises, may encourage other service providers to negotiate for price rises, and may lead to customers seeking more price concessions. On the other hand, a perception of financial hardship places the NFP in a better position to resist such calls and seek price concessions themselves.

\section{Costs of Reporting Losses}

Although profit maximisation is unlikely to be a goal of NFP executives, they must at least break even over time to continue as a going concern. Furthermore, as Australian NFPs are restricted in their ability to access the equity and debt markets, retained earnings take on additional importance as a source of growth capital and as buffer to mitigate financial shocks. Therefore, low but positive profitability is expected to send a positive signal of the executive team's ability to sustain the organisation as a going concern. A lack of confidence in the firm's ongoing sustainability might have costs in terms of reduced donations (as funders elect to support better run organisations) and the executive job market. Consistent with this reasoning, previous studies have found that NFPs intentionally manage their bottom line towards zero in order to achieve a target or implicitly signal their capability in financial management (Leone and Van Horn 2005; Ballantine et al. 2008; Verbruggen and Christiaens 2012). 
Other costs to Australian NFPs of reporting losses are likely to be minimal. Unlike their for-profit counterparts, NFPs are not permitted to distribute surpluses and so are not funded by equity. In the absence of an equity market, the motivation to avoid losses is expected to be less than in for-profit organisations. Australian NFPs are relatively immune from these costs because debt funding is not an important source of financial resources and performance bonuses are rare, especially as profit cannot be a driver of incentives given the inability to distribute profits.

Our Hypotheses

Not for profit executives incur costs when they report either profits or losses, as represented in Figure 1 below. The asymmetry in Figure 1 reflects the expectation that while very small profits are unlikely to have a significant impact on funders' perceptions of an NFP's neediness, even very small losses signal a weakness in the financial management ability of executives and the sustainability of the organisation. The implication of Figure 1 is that NFPs minimise reporting costs by reporting zero profits. In the presence of uncertainty, NFP executives are expected to respond to the asymmetric reporting costs by targeting, ex ante, a small profit. In addition to having a positive mean, the distribution of unmanaged earnings will be normally distributed because ex post earnings comprise of expected earnings and a normally distributed error term.

\section{Figure 1: Reporting Costs}

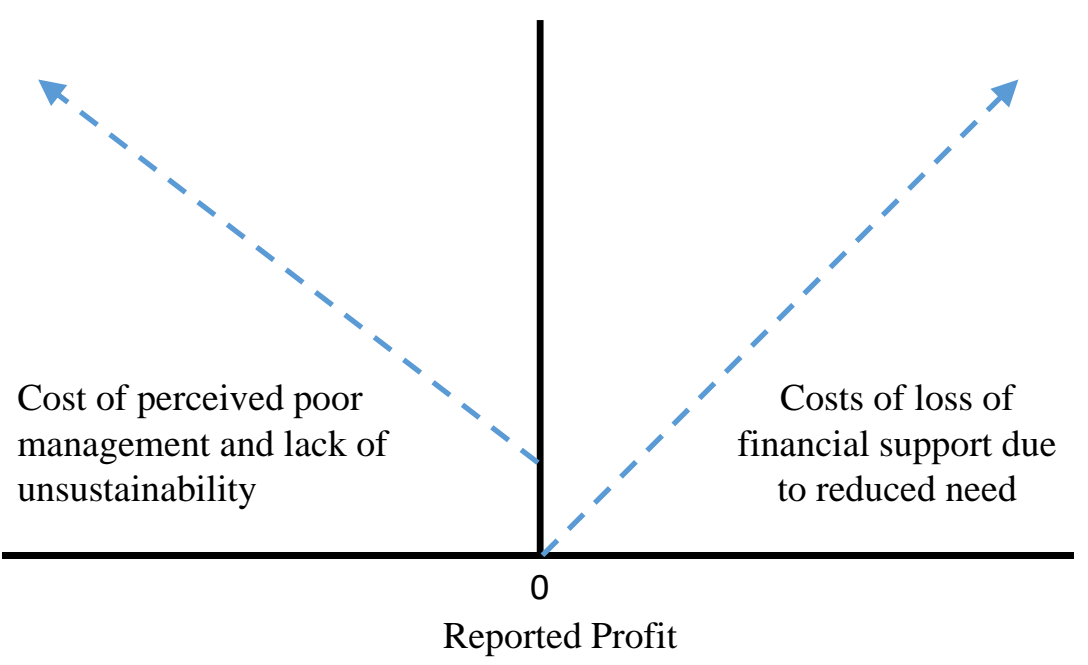


We hypothesise that NFP executives minimise reporting cost by making discretionary accruals that move reported profits toward some fixed point above but close to zero. When the NFP would otherwise report a loss, executives make income-increasing accruals, and when profits are excessive, they make income decreasing accruals. This leads to Hypothesis One.

H1: Discretionary accruals are positive (negative) when pre-managed earnings are negative (positive).

Following Burgstahler and Dichev (1997), Degeorge et al. (1999) and Leone and Van Horn (2005) we examine whether managers avoid reporting small losses. Given the asymmetry of reporting costs, NFP executives are expected to manage earnings to report profits that are positive and close to zero. If so, we hypothesise that the distribution of reported income will be non-normal, with abnormally low frequencies just to the left of zero.

H2: The distribution of earnings surrounding zero will be non-normal below and close to zero.

Ex post earnings management through discretionary accruals is not the only way that NFP executives can achieve their goal of reporting small profits; they can also make discretionary expenditure decisions during the year. The adjustment of discretionary expenditures to achieve earnings goals has been documented in the for-profit setting (e.g., Dechow and Sloan, 1991; Murphy and Zimmerman, 1993). Compared to for-profit firms, NFPs are likely to have a greater incentive to use discretionary expenditure to meet earnings goals because, as discussed previously, profitability is a constraint rather than an objective. Disability services is a workforce intensive industry and relies heavily on casual workers to provide care (Gilchrist, 2020), we assume that executives have significant discretion over changes to the level of care provided. We further assume that NFP executives will adjust service provision after estimating current year earnings based on last year's spending on service provision. Adjusting the level of service provision based on earnings allows the NFP to increase (decrease) the level of service provision and avoid reporting large profits (losses) that will increase reporting costs. This act is also related to the mission of the organisation, so there is an additional driver for this behaviour. This leads to the Hypothesis Three. 
H3: Spending on service provision is positively related to the availability of financial resources.

\section{Data}

The study utilises a unique database of the FY15 and FY16 financial results of 187 Australian NFP Disability Service Providers. The sample was collected iteratively between 2016 and 2018. We eliminate with insufficient data to estimate the modified Jones model, reducing the sample to 154 firms. In all, there are approximately 1,200 NFP disability service providers in Australia. Therefore, this sample represents approximately $12.8 \%$ of the population, though it is important to remember that these organisations self-selected to participate.

The data does not lend itself to increasing our understanding of the geographic spread of these organisations as it only provides the location of the organisation's head office while organisations can, and do, operate across state boundaries. Additionally, the data does not allow us to assess the age of entities due to the fact that this data is also not accessible via regulators' data sets.

Table 1 reports the descriptive statistics of the NFPs in our sample. The mean (median) revenue reported in thousands is $\$ 15,877$ ( $\$ 6,103)$, with the skewness being driven by a small number of relatively large service providers. Sample firms are significantly smaller than those examined in prior research but as discussed above are reflective of the Australian landscape. Total Assets (TA) is similarly skewed with a mean (median) of \$12,314 (\$5,516). Reported profit scaled by lagged assets has a mean and median of $7.01 \%$ and $4.06 \%$, respectively. The positive mean reported profit is consistent with NFPs setting positive profitability targets. Sample firms have their head offices geographically distributed according to expectations, with New South Wales and Victoria based firms in the majority (with 51 and 44 organisations, respectively) followed by Queensland and Western Australia (21 and 17) and the smaller states and territories accounting for the remaining 21 sample firms.

Although the preceding discussion provides us with some comfort, we cannot be certain that the organisations in our le are representative of the population of Australian disability service providers. Therefore, our results might not be generalisable to the broader population of disability service providers. 


\section{Table 1: Descriptive Statistics}

\begin{tabular}{|c|c|c|c|c|c|c|c|}
\hline Variable & Description & $\mathrm{N}$ & Mean & $\begin{array}{c}\text { Standard } \\
\text { Deviation }\end{array}$ & Minimum & Median & Maximum \\
\hline Revenue & Net Revenue (\$'000s) & 154 & 15,877 & 37,736 & 0 & 6,103 & 400,073 \\
\hline TA & Total Assets (\$'000s) & 154 & 12,314 & 21,895 & 120 & 4,516 & 145,057 \\
\hline Profitability & $\begin{array}{l}\text { Reported Profit ( } \$ 000 s) \\
\text { scaled by lagged assets }\end{array}$ & 154 & 0.0701 & 0.3030 & $(1.6566)$ & 0.0406 & 3.2086 \\
\hline DAJones & $\begin{array}{l}\text { Discretionary accruals } \\
\text { estimated with Jones } \\
\text { (1991) model }\end{array}$ & 154 & $(0.0579)$ & 0.2123 & $(0.9434)$ & $(0.0515)$ & 1.3155 \\
\hline DAModJones & $\begin{array}{l}\text { Discretionary accruals } \\
\text { estimated with modified } \\
\text { Jones (1995) model }\end{array}$ & 154 & $(0.0574)$ & 0.2129 & $(0.9475)$ & $(0.0502)$ & 1.3091 \\
\hline
\end{tabular}

\section{Empirical results}

In order to test for the existence of earnings management practice, discretionary accruals were considered as a proxy for earnings management (Jones 1991; Dechow et al. 1995; Verbruggen and Christiaens 2012). According to these authors, discretionary accruals represent managerial interventions in financial reporting policies in order to change the reported financial results. Discretionary accruals are therefore used to examine the earnings management. We report two estimates of discretionary accruals; the Jones (1991) model and the modified Jones model (Dechow et al 1995). We use the residuals from a first-stage equation for all measures of discretionary accruals, and, therefore by construction, mean discretionary accruals are approximately zero in both cases. The Jones model (1991) has been used extensively in forprofit and non-profit sectors (DeFond and Jiambalvo 1994; Dechow et al. 1995; Peasnell et al. 2000; Leone and Van Horn 2005; Verbruggen and Christiaens 2012, Nguyem and Soobaroyen 2018). It is estimated as follows:

$\frac{A C C_{i t}}{T A_{i t-1}}=\frac{\delta_{0 t}}{T A_{i t-1}}+\frac{\delta_{1 t} \Delta N E T_{\_} R E V_{i t}}{T A_{i t-1}}+\frac{\delta_{2 t} P P E_{i t}}{T A_{i t-1}}+\omega_{i t}$

Where:

- $\quad$ ACC $_{i t}$ is firm $i$ 's total accruals calculated as the change in non-cash current assets minus the change in current liabilities from year $t-1$ to year $t$ minus depreciation expense for year $t$;

- $\quad \Delta$ NET_REV $V_{i t}$ is firm $i$ 's change in net revenue from year $t$-1 to year $t$; 
- $\quad$ PPE $_{i t}$ is firm $i$ 's net property, plant and equipment as of the end of year $t$; and

- $\quad \mathrm{TA}_{i t-1}$ is firm $i$ 's total assets in year $t-1$.

The residuals from this model, which we refer to as DAJONES, are used as our first measure of discretionary accruals. We also use the modified Jones model (Dechow et al 1995) which has not been previously adopted in NFP research, despite its widespread adoption in the forprofit literature, due to the relative dearth of data in the NFP sector. The modified Jones model relaxes the assumption that firms do not use revenue recognition to manage earnings. This is an important assumption to relax in the NFP sector because a large amount of funding is received through grants in lump sum payments and firms have significant discretion on how they account for this. It is estimated as follows:

$\frac{A C C_{i t}}{T A_{i t-1}}=\frac{\delta_{0 t}}{T A_{i t-1}}+\frac{\delta_{1 t} \Delta N E T_{-} R E V_{i t}-\triangle R E C_{i t}}{T A_{i t-1}}+\frac{\delta_{2 t} P P E_{i t}}{T A_{i t-1}}+\omega_{i t}$

Where:

- $\quad \mathrm{ACC}_{i t}$ is firm $i$ 's total accruals calculated as the change in non-cash current assets minus the change in current liabilities from year $t-1$ to year $t$ minus depreciation expense for year $t$

- $\quad \Delta \mathrm{NET} \_\mathrm{REV}_{i t}$ is firm $i$ 's change in net revenue from year $t-1$ to year $t$;

- $\quad \Delta \mathrm{REC}_{\mathrm{it}}$ is firm $i$ 's change in accounts receivable from year $t$ - 1 to year $t$

- $\quad \mathrm{PPE}_{i t}$ is firm $i$ 's net property, plant and equipment as of the end of year $t$; and

- $\quad \mathrm{TA}_{i t-1}$ is firm $i$ 's total assets in year $t-1$.

The adjusted $R^{2}$ for the Jones model across all firms is 0.239 and the Modified Jones model is 0.237. This compares well to the Leone and Van Horn (2005) who reported an adjusted $\mathrm{R}^{2}$ for the Jones Model of 0.03 . We estimate the following OLS regression for our multivariate tests of Hypothesis 1.

$\mathrm{DA}_{i t}=\lambda_{0}+\lambda_{1} \mathrm{EBDA}_{i t}+\lambda_{2} \mathrm{PROFIT}_{i t-1}+\varepsilon$

Where:

- $\quad \mathrm{DA}_{i t}$ is the discretionary accruals of firm $i$ in period $t$ scaled by total assets at period $t-1$ 
- EBDA $_{i t}$ is the earnings before discretionary accruals for firm $i$ in period $t$ scaled by total assets in period $t-1$

- $\quad$ PROFIT $_{i t-1}$ is reported profit in period $t-1$ scaled by total assets in $t-1$.

EBDA takes on a different value for each discretionary accrual measure, and is equal to reported profit minus the particular discretionary accrual being used as the dependent variable. That is, when DA_JONES is the dependent variable, EBDA is equal to reported profit minus DA_JONES and when DA_MODJONES is the dependent variable, EBDA is equal to reported profit minus DA_MODJONES. In Hypothesis 1, we predict that NFP executives use discretionary accruals to manage earnings toward zero. Consequently, we expect a negative relation between $\mathrm{DA}_{i t}$ and $\mathrm{EBDA}_{i t}$. We include PROFIT ${ }_{i t}{ }^{-1}$ as an independent variable because past performance has been shown to be positively related to current-period discretionary accruals (Kothari et al., 2005). The coefficient on $\lambda_{2}$ is expected to be positive.

Table 2 reports the results of our OLS estimation of Equation 3, using both measures of discretionary accruals. As predicted by Hypothesis 1, the coefficient on EBDA $\mathrm{At}_{\text {it }}$ is negative and statistically significant for both discretionary accruals measures. The coefficient on PROFIT $_{\mathrm{it}-1}$ reflect expectations and is statistically significant in both regressions.

Table 2: Discretionary Accruals and NFP Performance

\begin{tabular}{llccl}
\hline Variable & \multicolumn{1}{c}{ Description } & $\begin{array}{c}\text { Predicted } \\
\text { Sign }\end{array}$ & $\begin{array}{r}\text { Jones (1991) model } \\
\text { parameters } \\
(t \text { statistic })\end{array}$ & $\begin{array}{c}\text { Modified Jones model } \\
(\text { Dechow et al 1995) } \\
(t \text { statistic })\end{array}$ \\
\hline Intercept & Intercept & & $-0.023(1.733)$ & $-0.023(-1.717)$ \\
EBDA & $\begin{array}{l}\text { Earnings before discretionary } \\
\text { accruals at time t }\end{array}$ & - & $-0.513(-10.340)^{* *}$ & $-0.516(-10.334)^{* *}$ \\
PROFIT & $\begin{array}{l}\text { Profit at time t-1 } \\
\text { Adjusted R2 }\end{array}$ & + & $0.440(4.338)^{* *}$ & $0.448(4.396)^{* *}$ \\
& $\mathrm{~N}$ & & & 0.468 \\
& & & 154 & 154 \\
\hline
\end{tabular}

It is possible that the results presented in Table 2 are biased towards supporting our hypothesis because of the existence of a mechanical relation between discretionary accruals and EBDA ${ }^{1}$.

\footnotetext{
${ }^{1}$ We estimate EBDA by subtracting discretionary accruals from reported profit. Since discretionary accruals will be subject to measurement error, the measurement error will also be present in EBDA.
} 
As a robustness check, we substitute EBDA with the variable EBDE (earnings before depreciation expense). This variable is constructed by adding back actual depreciation expense to reported profit. Table 3 reports the results of an OLS regression run with depreciation expense (scaled by lagged total asset) as the dependent variable and EBDE as the key explanatory variable. Lagged depreciation expense and lagged profit (both scaled by lagged assets) are included as control variables. The coefficient on EBDE is positive and significant at the $1 \%$ level, further supporting hypothesis 1 .

Table 3: Depreciation Expense and NFP Performance

\begin{tabular}{|c|c|c|c|}
\hline Variable & Description & Predicted Sign & Coefficient ( $t$ statistic) \\
\hline Intercept & Intercept & & $-0.008(-0.671)$ \\
\hline EBDE & $\begin{array}{l}\text { Earnings before actual } \\
\text { accruals at time } t\end{array}$ & + & $0.352(13.120)^{* *}$ \\
\hline PROFIT & Profit at time t-1 & - & $-0.254(3.934)^{* *}$ \\
\hline \multirow[t]{3}{*}{$\mathrm{ACt}-1$} & Accrual Account t-1 & $?$ & $1.415(6.250)^{* *}$ \\
\hline & Adjusted R2 & & 0.665 \\
\hline & $\mathrm{N}$ & & 153 \\
\hline
\end{tabular}

Hypothesis 2 is examined by assessing the normality of the distribution of returns close to zero. As shown in Figure 1, the cost of reporting small losses is greater than the cost of reporting small profits, so NFP executives will tend to make ex ante operating decisions with a view to achieving slight profitability to reduce the likelihood of reporting a loss ex post, after realising exogenous shocks. If earnings are not managed with discretionary accruals and executives are well calibrated, the distribution of reported earnings should be normally distributed because ex post earnings reflect ex ante targets plus a normally distributed error. Therefore, under the null hypothesis the first interval of earnings observations below zero will be approximately equal to the average number of earnings observations in the intervals just to the left and just to the right of zero. The presence of earnings management is indicated by an abnormal distribution of reported earnings close to zero (Leone and Van Horn 2005; Ballantine et al. 2008; Verbruggen and Christiaens 2012)

We test Hypothesis 2 by producing frequency distributions of reported earnings and pre-managed earnings (earnings without discretionary accruals), in line with procedures by Burgstahler and Dichev (1997) and plotting histograms of reporting earnings. Figure 2 displays two histograms of EBDA (earnings minus estimated discretionary accruals, DAJONES, from 
model 1) and earnings scaled by total assets at intervals of $0.5 \%$. Panel $\mathrm{A}$ is the distribution of EBDA and Panel B is the distribution of PROFIT.

Figure 2: Earnings Histograms

Panel A: Distribution of Earnings before Discretionary Accruals scaled by assets

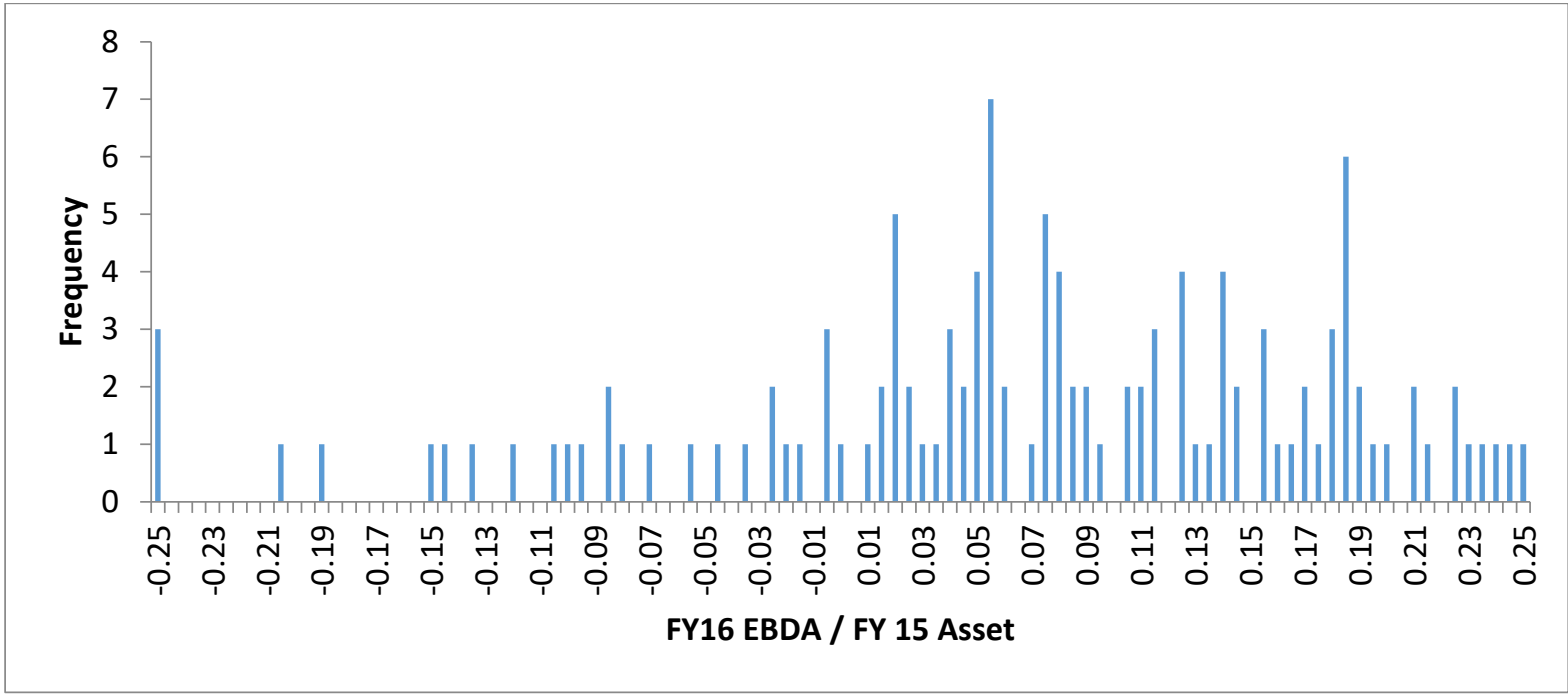

Panel B: Distribution of Reported Profit before Tax

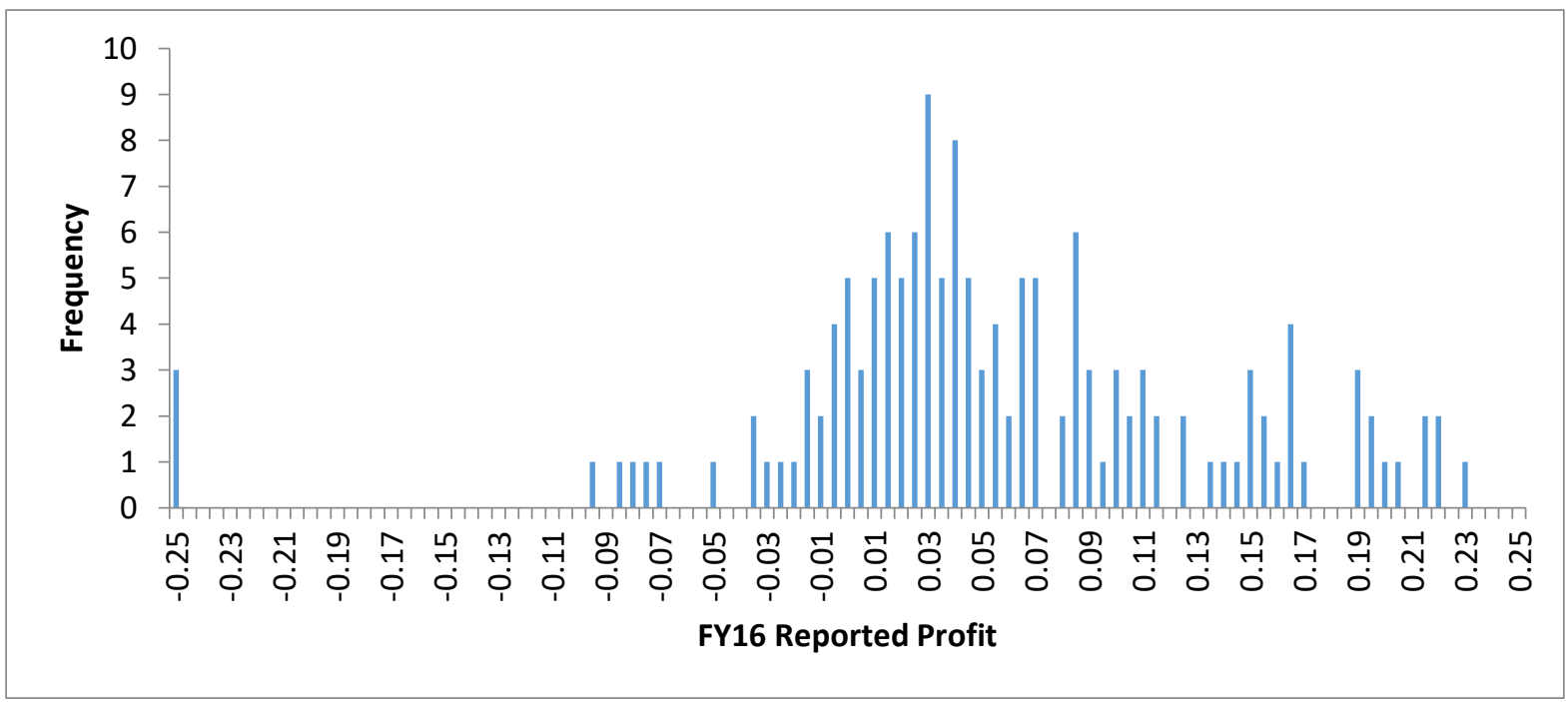

There is a noticeable drop in the number of observations in the distribution of reported profit around zero in panel B. This drop is similar to that reported by Burgstahler and Dichev (1997) and Leone and Van Horn (2005) who plot the distribution of net income scaled by market value. Burgstahler and Dichev interpret this discontinuity as evidence that managers with small losses make income increasing discretionary accruals to avoid losses. In comparing the distribution of EBDA in Figure 2, Panel A, to Panel B, it appears that many of 
our sample firms move earnings in the direction of zero but slightly positive. The mean (median) of EBDA is $11.5 \%$ (9.5\%) and the mean (median) for reported profit is $7.0 \%(4.1 \%)$ suggesting that overall, discretionary accruals do lower reported earnings. Discretionary accruals also have the effect of reduce the variance in reported earnings. The standard deviation is reduced from 0.33 for EBDA to 0.30 for reported profit. A one-tailed $F$-test for differences in variances rejects the null that the variances of these two distributions are the same at $p<0.01$. This is consistent with managers using discretionary accruals to reduce more extreme values of reported profit.

The results presented in Figure 2 support our hypothesis that NFP executive utilise accruals to present small positive profits. When they would otherwise report a small loss, NFPs make income-increasing accruals. An alternative explanation, that the non-normal distribution of earnings is a result of operating decisions, is not supported because Panel A, which plots earnings before discretionary accruals, does not have the same discontinuity.

The first two hypotheses examined the extent to which NFPs utilise accruals to minimise reporting costs. The third hypothesis examines whether NFP executives utilise discretionary operational spending to minimise reporting costs. Due to reliance on casual workers, we assume that NFPs face sufficiently minimal costs when increasing or decreasing their service provision that changes in personnel costs are essentially discretionary. Adjusting service provision (proxied by personnel expenses) allows the disability services provider to increase (decrease) the level of care provided and avoid reporting large profits (losses) that will increase reporting costs.

To test hypothesis 3, we examine whether employee expenditure is an increasing function of income before employee expenditure, using Equations 4 and 5

$\begin{array}{lr}\triangle \text { EMPLOYEE }, i t=\lambda_{0}+\lambda_{1} \text { PREPROFIT } & (\text { Eq 4) } \\ \triangle \text { EMPLOYEE }=\lambda_{0}+\lambda_{1} \Delta \text { REVENUE } & \text { (Eq 5) }\end{array}$

We calculate PREPROFIT by adding back current year employee expense and subtracting the prior year's employee expense. The dependent variable, $\triangle E M P L O Y E E$, is the change in employee expense scaled by total assets. Table 4 reports the results of an OLS regression of $\triangle E M P L O Y E E$ against PREPROFIT. The second model includes $\triangle$ REVENUE to capture increases in employee expenses resulting from overall increases in revenue. The coefficient on PREPROFIT is positive and significant in both models, consistent with $\mathrm{H} 3$, that 
Gilchrist, Etheridge \& Liu

Earnings Management in Australian Not-for-profit Disability Services

NFPs adjust employee expenditure based on available profits. This indicates that NFP managers view profitability as a constraint.

Table 4: Change in employee expenses vs profit before changes in employee expenses

\begin{tabular}{llccc}
\hline Variable & Description & $\begin{array}{c}\text { Predicted } \\
\text { Sign }\end{array}$ & $\begin{array}{c}\text { Coefficient } \\
(\text { t statistic })\end{array}$ & $\begin{array}{c}\text { Coefficient } \\
(\text { t statistic })\end{array}$ \\
\hline Intercept & Intercept & & $0.028(2.066)^{*}$ & $0.033(2.503)^{*}$ \\
PREPROFIT & $\begin{array}{l}\text { Profit before change in } \\
\text { employee expenses }\end{array}$ & + & $0.477(18.515)^{* *}$ & $0.314(5.991)^{* *}$ \\
$\Delta$ REV & Change in Revenue & + & & $0.151(3.507)^{* *}$ \\
& Adjusted R2 & & 0.691 & 0.712 \\
& $\mathrm{~N}$ & & 154 & 154 \\
\hline
\end{tabular}

\section{Concluding remarks}

Since we find that NFPs manage expenditure to maintain profit close to zero, our findings have implications for the sustainability of the sector. Indeed, making a profit is as critical to NFPs as it is for For-Profits as they allow the balance sheet to be strengthened, cash reserves to be established against future instability, and for assets to be replaced when needed. Without being profitable, NFPs are signalling that they are less sustainable than they should be and they are also reinforcing a common belief that NFPs should not make a profit, thus reinforcing the attitude of funders and others that these organisations do not need to consider the longer term (Gilchrist, 2020).

This paper seeks to contribute to research into the Australian NFP sector in order to better understand the sustainability of the sector and the motivations Disability services NFPs have multiple stakeholders with an interest in their financial performance. The expectations of these stakeholders result in Australian NFPs facing reporting costs that are increasing in both reported profits and reported losses. Our results reveal that Australian NFP disability services firms view profitability as a constraint and minimise reporting costs by managing earnings toward zero after pre-managed earnings can be reliably estimated by management.

In addition, we find evidence reporting costs for small losses are greater than reporting profits of equivalent magnitudes. This reporting cost asymmetry arises because funders will accept a small profit before re-assessing the NFPs need for further resources, even a small loss is a signal that management is unable to sustainably meet the organisation's goals. 


\section{References}

ACNC (2020). Australian Charities Report 2018. Melbourne, Australian Charities and Not-forprofits Commission.

Ballantine, J., Forker, J., \& Greenwood, M. (2008). The governance of CEO incentives in English NHS hospital trusts. Financial Accountability \& Management, 24, 385-410.

Barth, M., Elliot, J., Finn, M., 1999. Market rewards associated with patterns of increasing earnings. Journal of Accounting Research 37, 387-414.

Brickley, J., Van Horn, R.L., 2002. Managerial incentives in nonprofit organizations: evidence from hospitals. Journal of Law and Economics, 227-250.

Buchheit, S., Parsons, L., 2006. An experimental investigation of accounting information's influence on the individual giving process. Journal of Accounting and Public Policy 25, 666686

Burgstahler, D., Dichev, I., 1997. Earnings management to avoid earnings decreases and losses. Journal of Accounting and Economics 24, 99-126.

Dechow, P., Skinner, D., 2000. Earnings management: Reconciling the views of accounting academics, practitioners, and regulators. Accounting Horizons 14, 235-250.

Dechow, P., Sloan, R., 1991. Executive incentives and the horizon problem: an empirical investigation. Journal of Accounting and Economics 14, 51-89.

Dechow, P., Sloan, R., Sweeney, A., 1995. Detecting Earnings Management. The Accounting Review 70(2), 193-225

DeFond, M., Jiambalvo, J., 1994. Debt covenant violation and manipulation of accruals. Journal of Accounting and Economics 17, 145-176.

DeFond, M., Park, C., 1997. Smoothing income in anticipation of future earnings. Journal of Accounting and Economics 23, 115-139.

Degeorge, F., Patel, J., Zeckhauser, R., 1999. Earnings management to exceed thresholds. The Journal of Business 72, 1-34.

Fama, E., Jensen, M., 1983a. Separation of ownership and control. Journal of Law and Economics, 301-325. 
Fama, E., Jensen, M., 1983b. Agency problems and residual claims. Journal of Law and Economics, 327-349.

Frank, R., Salkever, D., 1994. Nonprofit organizations in the health sector. Journal of Economic Perspectives 8, 129-144.

Frank, R., Salkever, D., Mitchell, J., 1990. Market forces and the public good: competition among hospital and provision of indigent care. In: Scheffler, R.M., Louis, F.R. (Eds.), Advances in Health Economics and Health Services Research, vol. 10. JAI Press, Greenwich, pp. 131-158.

Frumkin, P. (2005). On Being Nonprofit: A Conceptual and Policy Primer. London, Harvard University Press

Gaver, J., Gaver, K., Austin, J., 1995. Additional evidence on bonus plans and income management. Journal of Accounting and Economics 19, 3-28.

Gilchrist, D. J. (2017). Issues Paper: Better Financial Reporting for Australian NFPs. Canberra, Independent Centre for Applied Not-for-profit Research: 43.

Gilchrist, D. J. and R. Simnett (2019). "Research Horizons for Public and Private Not-for-profit Sector Reporting: Moving the Bar in the Right Direction." Accounting and Finance 59(1): 26.

Gilchrist, D. (2020a). All the Best Intentions: A Review of a Sub-National Attempt at Reshaping the Not-for-profit/Public Sector Nexus. Designing Governance Structures for Performance and Accountability: Developments in Australia and Greater China. T.-T. S. Andrew Podger, John Wanna, Hon. S. Chan, and Meili Niu. Canberra, Australian National University Press.

Gilchrist, D. (2020b). "Silver Bullets and TED Talks: Sketching Ideas on the Government/Not-forprofit Nexus in the Australian Welfare State." Third Sector Review 26(2): 20.

Gilchrist, D., P. Knight and T. Emery (2020). Green Paper 1: Data Assets, Efficiency and the NDIS. Australian Disability Services System Research Project. D. J. Gilchrist. Perth, University of Western Australia.

Guidry, F., Leone, A., Rock, S., 1999. Earnings-based bonuses and earnings management by business-unit managers. Journal of Accounting and Economics 26, 113-142.

Healy, P., Wahlen, J., 1999. A review of the earnings management literature and its implications for standard setting. Accounting Horizons 13, 365-383.

Heimovics, R., Herman, R., Jurkiewicz, C. 1993. Executive leadership and resource dependence in Nonprofit organisations: A frame analysis. Public Administration Review 53, 419-427. 
Jegers, M. 2013. Do non-profit organisations manage earnings? An empirical study. Voluntas 24, 953-968.

Jones, J., 1991. Earnings management during import relief investigations. Journal of Accounting Research 29, 193-228.

Kothari, S.P., Leone, A., Wasley, C., 2005. Performance matched discretionary accrual measures. Journal of Accounting and Economics 39, 163-197.

Leone, A., Rock, S., 2002. Empirical tests of budget ratcheting and its effect on managers' discretionary accrual choices. Journal of Accounting and Economics 33, 43-76.

Leone, A., Van Horn., R., 2005. How do nonprofit hospitals manage earnings? Journal of Health Economics 24, 815-837.

Murphy, K., Zimmerman, J., 1993. Financial performance surrounding CEO turnover. Journal of Accounting and Economics 16, 273-315.

Nguyen, T. and T. Soobaroyen 2019. Earnings Management by Non-profit Organisations: Evidence from UK Charities." Australian Accounting Review 88(29): 19.

Okten, C., Weisbrod, B.A., 2000. Determinants of donations in private nonprofit markets. Journal of Public Economics 75, 255-272.

Peasnell, K., Pope, P., Young., S., 2012. Detecting earnings management using cross-sectional abnormal accruals models. Accounting and Business Research 30, 313-326.

Roychowdhury, S. 2006. Earnings management through real activities manipulation. Journal of Accounting and Economics 42, 335-370.

Schipper, K. 1989. Commentary on earnings management. Accounting Horizons 3, 91-102.

Tinkleman, D., 1999. Factors affecting the relation between donations to not-for-profit organizations and an efficiency ratio. Research in Government and Nonprofit Accounting 10, 135-161.

Trueman, B., Titman, S., 1988. An explanation for accounting income smoothing. Journal of Accounting Research 26, 127-139.

Vansant, B. 2016. Institutional Pressures to Provide Social Benefits and the Earnings Management Behavior of Nonprofits: Evidence from the U.S. Hospital Industry. Contemporary Accounting Research 33, 24. 
Verbruggen, S., Christiaens, J. 2012. Do non-profit organizations manage earnings toward zero profit and does governmental financing play a role? Canadian Journal of Administrative Sciences 29, 205-217.

Walker, M. 2013. How far can we trust earnings numbers? What research tells us about earnings management. Accounting and Business Research 43, 445-481.

Zhai, L., J. Watson, D. Gilchrist and R. Newby 2017. Nonprofit Vulnerability: An Exploratory Study. Financial Accountability and Management 33(4): 18. 